\title{
Effect of Pre-exposure Light on the First Positive Phototropic Curvature in Dark-grown Radish Seedlings
}

\author{
Hisashi Kato-NoguchI \\ Department of Biochemistry and Food Science, Faculty of Agriculture, \\ Kagawa University, Miki-cho, Kagawa 761-0795, Japan
}

(Received September 1, 1997)

\begin{abstract}
Effect of pre-exposure light on the first positive phototropic curvature in dark-grown radish seedlings(Raphanus sativus L. cv. Miyashige) was investigated. When the seedlings are pre-exposed to white-light from above, the magnitude of the first positive phototropic curvature of the hypocotyls responding to unilateral blue-light pulseirradiation was enhanced. The pre-exposure treatment to the hypocotyls only accelerated the development of the phototropic curvature. Treatment to the apex and cotyledons had no effect on the increase of the phototropic curvature. These results suggest that the pre-exposure treatment enhances the first positive phototropic curvature of the dark-grown radish seedlings, and the pre-exposure light may be perceived by the phototropic responding organ, the hypocotyl itself.
\end{abstract}

\section{INTRODUCTION}

Since the investigation by Briggs (1960) on dose-response relations between the energy of light stimulus and magnitude of the phototropic curvature in maize and oat seedlings, much research has been conducted to establish the dose-response curves for phototropism in many plant species (Dennison, 1979; Pickard, 1985). In these experiments, many of the dark-grown seedlings show two types of positive response, "first positive" and "second positive" phototropic curvature (Briggs, 1964 ; Steyer, 1967 ; Iino et al., 1984 ; Steinitz and Poff, 1986). The first positive response can be induced only by short exposures to unilateral light. The induced curvature is small, not exceeding $30^{\circ}$, and the response obeys the Bunsen-Roscoe law. The second positive response can be induced by prolonged irradiations. A strong bending response (curvature $30-90^{\circ}$ ) is typical for the second positive phototropism (Briggs, 1964 ; Dennison, 1979).

The second positive phototropic curvature in many plants was enhanced by pre-exposure treatments with red- (Kang and Burg, 1974; Shuttleworth and Black, 1977) or blue-light (Blaauw and Blaauw-Jansen, 1970; Franssen and Bruinsma, 1981), and with white-light (Franssen and Bruinsma, 1981; Hart and MacDonald, 1981; Kato-Noguchi, 1997). On the other hand, the pre-exposure treatments decreased the first positive phototropic curvature in several plants (Zimmerman and Briggs, 1963 ; Pickard, 1985). From these experiments, the pre-exposure treatments were concluded to prevent the first positive phototropic responsive system and to stimulate the second positive responsive system (Steyer, 1967 ; Everett, 1974).

Recently, it was reported, however, that the first positive phototropic curvature was enhanced by red-light pre-exposure treatment in maize coleoptile (Iino, 1988) and by both redand blue-light pre-exposure treatments in Arabidopsis thaliana seedlings (Janoudi and Poff, 
1992). Thus, the purpose of the present research was to investigate whether the pre-exposure treatment increase the first positive phototropic curvature in dark-grown radish seedlings and to determine the perception site of the pre-exposure light in the seedlings.

\section{MATERIALS AND METHODS}

Plant material: Seeds of radish (Raphanus sativus L. cv. Miyashige) were germinated in moist vermiculite in the dark at $25^{\circ} \mathrm{C}$ for $3 \mathrm{~d}$ as previously described (Kato-Noguchi, 1997). Uniform 3-d-old seedlings were transferred, in groups of 10 , to plastic containers $(12 \times 25 \times 10$ (height) $\mathrm{cm}$ ), filled with fresh vermiculite and grown in darkness at $25^{\circ} \mathrm{C}$ for one further $\mathrm{d}$. All handling after sowing was performed under dim green safe-light $\left(3 \mathrm{~mW} \mathrm{~m}^{-2}\right)$.

Light source and phototropic experiments : Blue-light $\left(6 \mathrm{~mW} \mathrm{~m}^{-2}\right.$ at plant level ; emission peak, $450 \mathrm{~nm}$; half band width, $431-479 \mathrm{~nm}$ ) for phototropic stimulus was provided from a blue fluorescent lamp (Fl-20S-B, National, Tokyo) with three layers of film (Super-Gel No. 85, RDS, Ltd., Tokyo), since blue-light is the most effective light for phototropic curvature in many plant species (Curry, 1969 ; Dennison, 1979; Pickard, 1985).

Phototropic experiments were carried out at $25^{\circ} \mathrm{C}$ in a black box to avoid light reflection as described previously (Kato-Noguchi, 1997). The 4-d-old dark-grown seedlings (hypocotyl length about $40 \mathrm{~mm}$ ) were placed at $35 \mathrm{~cm}$ distance from the blue fluorescent lamp installed in a small black box with a $3-\mathrm{cm}$ wide horizontal slit. Unilateral blue-light pulse-irradiation through the slit was given over all the seedlings for $30 \mathrm{~s}$, and then the seedlings were transferred to darkness at $25^{\circ} \mathrm{C}$. The phototropic curvature of the seedlings was determined by measuring the angle between the hypocotyl base and the tangent to the apex of the seedlings with a protractor.

To obtain a phototropic dose-response curve, the unilateral pulse-irradiation of the blue-light was given to the seedlings for various durations. Thereafter, the seedlings were transferred to darkness at $25^{\circ} \mathrm{C}$ and the phototropic curvatures were measured $100 \mathrm{~min}$ after the start of the pulse-irradiation.

Pre-exposure treatments were carried out as described previously (Kato-Noguchi, 1997). The 4-d-old dark-grown seedlings were exposed continuously from above with a white fluorescent lamp $\left(0.1 \mathrm{~W} \mathrm{~m}^{-2}\right.$ at plant level ; Fl-20S-PG, National) for $1 \mathrm{~h}$ at $25^{\circ} \mathrm{C}$ just before the unilateral blue-light pulse-irradiation.

Covering treatments were also carried out according to Kato-Noguchi (1997) to investigate the perception site of the pre-exposure light. The hypocotyls or the apex and cotyledons of the seedlings were covered with aluminum foil during the pre-exposure treatments. The stress of the covering treatments did not interfere with the phototropic curvature (KatoNoguchi, 1997).

\section{RESULTS AND DISCUSSION}

Phototropic dose-response curve induced by unilateral blue-light pulse-irradiation was determined in dark-grown radish seedlings (Fig. 1). According to the terminology used for phototropism (Briggs, 1963; Pickard,1985), the responses of the radish hypocotyls to stimuli up to about $100 \mathrm{~s}$ duration could be the first positive phototropic curvature, and the responses to stimulus durations longer than $300 \mathrm{~s}$ could be the second positive phototropic curvature. The seedlings responded with curvature of no more than $8^{\circ}$ in the first positive dose range (Fig. 1). This dose-response curve reported here is comparable with the curves of Burpee's white radish (Everett, 1974) and Sakurajima radish seedlings (Sakoda et al., 1988).

Figure 2 shows the time course of the change in phototropic curvature of dark-grown 


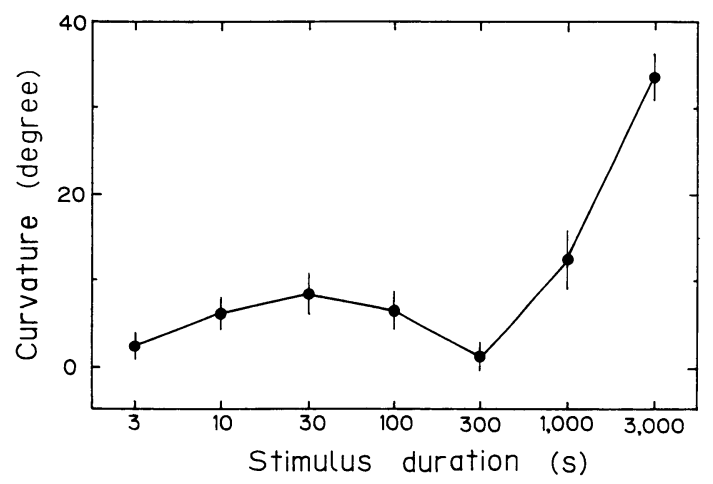

Fig. 1 Dose-response curve for phototropic curvature of dark-grown radish seedlings.

Dark-grown, 4-d-old seedlings were unilaterally irradiated with blue-light pulse at $6 \mathrm{~mW} \mathrm{~m} \mathrm{~m}^{-2}$ for various durations. After irradiation, the seedlings were transferred to darkness. The curvature of the seedlings was measured $100 \mathrm{~min}$ after the onset of the phototropic stimulus. Means $\pm \mathrm{SE}$ from three replicate experiments with 20 plants each are shown.

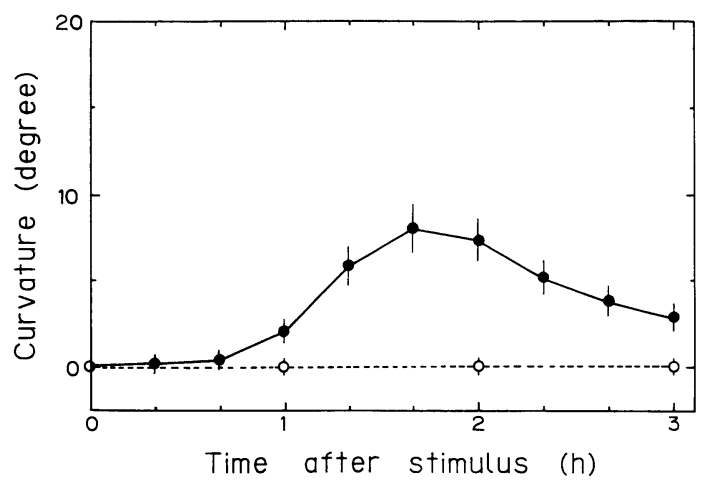

Fig. 2 Changes in phototropic curvature of dark-grown radish seedlings.

Dark-grown, 4-d-old seedlings were unilaterally irradiated with blue-light pulse at $6 \mathrm{~mW} \mathrm{~m}^{-2}$ for $30 \mathrm{~s}$, and transferred to darkness. The curvature of the seedlings was measured at indicated times (O). Control plants remained in total darkness $(O)$. Means \pm SE from three replicate experiments with 20 plants each are shown.

radish seedlings induced by 30 -s blue-light pulse-irradiation at an intensity of $6 \mathrm{~mW} \mathrm{~m}^{-2}$. This stimulus energy of blue-light is within the range of energy inducing the peak response in the first positive phototropic curvature (Fig. 1). After the pulse-irradiation, the phototropic curvature began to develop by $20-40 \mathrm{~min}$, and curvature toward the light source increased with time to a maximum of about $8^{\circ}$ at $100 \mathrm{~min}$. Curvature then decreased in a "straightening phase" due to an autotrophic or a countering gravitropic response, resulting in a loss of about $5^{\circ}$ by $180 \mathrm{~min}$ after the pulse-irradiation (Nick and Schäfer, 1988; Steinitz et al., 1988; Orbović and Poff, 1991). In contrast, control seedlings showed no significant curvature (Fig. 2).

The effect of pre-exposure treatment with white-light on the first positive phototropic curvature was examined by measuring the time course for the curvature (Fig. 3). The result shows that the curve shape of phototropic response of pre-exposed seedlings does not appear to be different from that of the dark-grown seedlings (Figs. 2 and 3). The lag phase, time to 


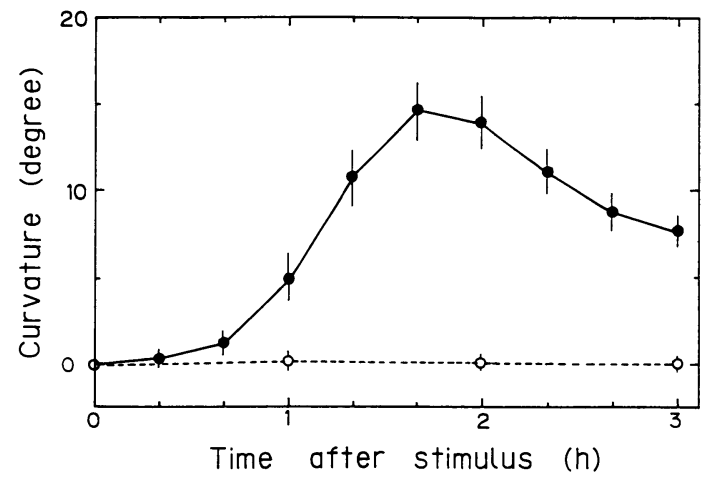

Fig. 3 Changes in phototropic curvature of pre-exposed dark-grown radish seedlings.

Dark-grown, 4-d-old seedlings were unilaterally irradiated with blue-light pulse at $6 \mathrm{~mW} \mathrm{~m}^{-2}$ for $30 \mathrm{~s}$ after pre-exposure treatment with white light from above for $1 \mathrm{~h}$ at $0.1 \mathrm{~W} \mathrm{~m}^{-2}$, and transferred to darkness. The curvature of the seedlings was measured at indicated times (O). Control plants remained in total darkness $(\bigcirc)$. Means \pm SE from three replicate experiments with 20 plants each are shown.

Table 1 Covering effect on the first positive phototropic curvature. The hypocotyls or the apex and cotyledons of the 4-d-old dark-grown seedlings were covered with aluminum foil during pre-exposure treatment, and then, the foil was removed and the seedlings were unilaterally irradiated with blue-light pulse for $30 \mathrm{~s}$. The phototropic curvature was measured $100 \mathrm{~min}$ after the pulse irradiation. Intact seedlings were not covered during the preexposure treatment. Means \pm SE from three replicate experiments with 20 plants each are shown.

\begin{tabular}{lcc}
\hline & \multicolumn{2}{c}{ Curvature (degree) } \\
\cline { 2 - 3 } Treatments & $\begin{array}{c}\text { Dark-grown } \\
\text { seedlings }\end{array}$ & $\begin{array}{c}\text { Pre-exposed } \\
\text { seedlings }\end{array}$ \\
\hline Intact & $8 \pm 1$ & $15 \pm 3$ \\
Apex and cotyledons covered & $7 \pm 2$ & $14 \pm 3$ \\
Hypocotyl covered & $8 \pm 2$ & $7 \pm 2$ \\
\hline
\end{tabular}

maximum curvature, and the following straightening phase are all similar. However, the magnitude of curvature was greater in the pre-exposed seedlings than in the dark-grown ones. By $100 \mathrm{~min}$, the phototropic curvature of the pre-exposed seedlings developed about 2-fold compared with that of the dark-grown seedlings. These results indicate that the pre-exposure treatment may enhance the first positive phototropic curvature in the dark-grown seedlings.

The perception site of the pre-exposure light enhancing the first positive phototropic curvature was investigated (Table 1). The hypocotyls or the apex and cotyledons of the dark-grown seedlings were covered with aluminum foil during pre-exposure treatment. After the foil was removed, the seedlings were unilaterally irradiated with the 30 -s blue-light pulse, and their curvature were measured after $100 \mathrm{~min}$. The enhancement effect of the pre-exposure on the curvature was prevented by covering the hypocotyl, whereas covering the apex and cotyledons showed no effect on the enhancement of the phototropic curvature. Thus, these results show that only the pre-exposure treatment on the hypocotyls induced the development of the first phototropic curvature.

In the previous study, the second positive phototropic curvature of dark-grown radish seedlings was enhanced by the pre-exposure treatment, and the site of perception of the light 
to enhance the second positive phototropic curvature was in the hypocotyls of the seedlings (Kato-Noguchi, 1997). The findings in the present research indicate that the pre-exposure treatment also enhances the first positive phototropic curvature in the dark-grown radish seedlings and that the site of perception of the pre-exposure light may be located within the phototropic responding organ, the hypocotyl itself.

\section{REFERENCES}

Blaauw, O. H., Blaauw-Jansen G. 1970. The phototropic responses of Avena coleoptiles. Acta Bot. Neerl. 19 : 755-764.

Briggs, W. R. 1960. Light dosage and phototropic responses of corn and oat coleoptiles. Plant Physiol. 35 : 951-962.

Briggs, W. R. 1963. The phototropic responses of higher plants. Annu. Rev. Plant Physiol. 14 : 311-352.

Briggs, W. R. 1964. Phototropism in higher plants. In "Photophysiology" (ed. by Giese, A. C.). Academic Press, London, p 223-271.

Curry, G. M. 1969. Phototropism. In "The Physiology of Plant Growth and Development" (ed. by Wilkins, M. B.). McGraw-Hill, New York, p 241-273.

Dennison, D. S. 1979. Phototropism. In "Physiology of Movements. Encyclopedia of Plant Physiology Vol. 7” (ed. by Haupt, W., Feinleib, M. E.). Springer-Verlag, Berlin, p 506-566.

Everett, M. 1974. Dose-response curves for radish seedling phototropism. Plant Physiol. 54 : 222225.

Franssen, J. M., Bruinsma, J. 1981. Effects of different wavelengths on phototropic sensitivity of sunflower Helianthus annuus seedlings. Phytomorphology $30: 344-358$.

Hart, J. W., MacDonald, I. R. 1981. Phototropic responses of hypocotyls of etiolated and green seedlings. Plant Sci. Lett. 21 : 151-158.

Iino, M., Briggs, W. R., Schäfer, E. 1984. Phytochrome-mediated phototropism in maize seedling shoots. Planta 160 : 41-51.

Iino, M. 1988. Desensitization by red and blue light of phototropism in maize coleoptiles. Planta 176 : 183-188.

Janoudi, A.-K., Poff, K. L. 1992. Action spectrum for enhancement of phototropism by Arabidopsis thaliana seedlings. Photochem. Photobiol. 56 : 655-659.

Kang, B. G., Burg, S. P. 1974. Red light enhancement of the phototropic response of etiolated pea stems. Plant Physiol. 53 : 445-448.

Kato-Noguchi, H. 1997. Light enhancement of the second positive phototropic curvature in dark-grown radish seedlings. Environ. Control in Biol. 35: 191-196.

Nick, P., Schäfer, E. 1988. Interaction of gravi- and phototropic stimulation in the response of maize (Zea mays L.) coleoptiles. Planta 173 : 213-220.

Orbović, V., Poff, K. L. 1991. Kinetics for phototropic curvature by etiolated seedlings of Arabidopsis thaliana. Plant Physiol. 97 : 1470-1475.

Pickard, B. G. 1985. Roles of hormones in phototropism. In "Hormonal Regulation of Development III. Encyclopedia of Plant Physiology Vol. 11" (ed. by Pharis, R. P., Reid, D. M.). Springer-Verlag, Berlin, p 365-417.

Sakoda, M., Matsuoka, T., Sando, S., Hasegawa, K. 1988. Phototropism in hypocotyls of radish V. Lateral distribution of cis- and trans-raphanusanins and raphanusamide in various phototropisms induced by unilateral broad blue light. J. Plant Physiol. 133 : 110-112.

Shuttleworth, J. E., Black, M. 1977. The role of cotyledons in phototropism of de-etiolated seedlings. Planta 135 : 51-55.

Steinitz, B., Poff, K. L. 1986. A single positive phototropic response induced with pulsed light in hypocotyls of Arabidopsis thaliana seedlings. Planta 168 : 305-315.

Steinitz, B., Best, T., Poff, K. L. 1988. Phototropic fluence-response relations for Avena coleoptiles on a clinostat. Planta 176 : 189-195. 
Steyer, B. 1967. The dose response relations in geotropic and phototropic stimulation : comparison of mono-with dicotyledonous plants. Planta 77 : 277-286.

Zimmerman, B. K., Briggs, W. R. 1963. Phototropic dosage-response curves for oat coleoptiles. Plant Physiol. 38 : 248-253.

〈和文抄録〉

\section{暗所で育てたダイコン芽生えにおいて前照射光が \\ 光屈性一次正届曲反応に与える影響}

加 藤尚

香川大学農学部

暗所で育てた 4 日齢のダイコン (品種 宮重) 芽生えにおいて, 光屈性一次正屈曲反応に対する 前照射光の影響について調べた. 芽生えの上方からの白色光照射による前処理は, その後の横方向 からの短時間の青色光に対する光屈性一次正屈曲反応を増加させた.この前照射の光屈性反応に 対する効果は, 芽生えの下胚軸に行ったときだけ光屈性反応を促進させ, 芽生えの先端部や子葉に 行っても効果は無かった. 以上の結果は, 前照射処理は暗所で育てたダイコン芽生えの光屈性一次 正屈曲反応を増加させること, この前処理の光は光屈性の反応器官である下肧軸自体で感受され ることを示唆している. 